\title{
Parenting Styles during the Covid-19 Pandemic: A Conception of Islamic Family Law
}

\author{
Baharuddin \\ Lecturer at the State Islamic Institute (IAIN) Bone \\ E-mail:bahar88udin@gmail.com
}

\section{Abstract}

The covid-19 pandemic situation has led to many changes in living conditions and various activities that are mostly carried out at home in order to reduce and prevent the chain of transmission of the corona-19 virus. This study aims to provide an illustration of the role of parents at home during the Covid19 pandemic situation by providing the rights that must be given to children by correlating them with the concept of childcare in Islamic family law. The urgency in education studies in the review of Islamic family law is to emphasize the position of parents who are not only responsible for providing a living, including in matters of success in education. This is a conceptual study, which seeks to explore the concept of childcare that is built in Islamic family law. The findings in this study indicate that childcare according to Islamic family law in the covid-19 pandemic situation, namely: 1) teaching children to do good and keep away from badness, this is done by way of parents giving examples and accompanying children when learning, 2) Parenting with affection, this care is done by providing safety and guidance to children, 3) Fulfilling the needs of children. In the conception of Islamic family law it is known as hadanah rights or child care which is widely understood, both in terms of livelihood to children's intelligence. The implication of this finding is that during the pandemic, parents have a significant role, in addition to living needs, parents are also required to ensure children's intelligence through the fulfillment of education.

Situasi pandemi covid-19 telah memberikan banyak perubahan tatanan hidup dan berbabagi aktivitas yang banyak dilakukan di rumah demi mengurangi dan mencegah rantai penularan virus corona-19. Penelitian ini bertujuan memberikan ilustrasi akan peran orang tua di rumah dalam situasi pandemi covid-19 dengan memberikan hak-hak yang harus diberikan kepada anak dengan mengkorelasikannya dengan konsep pemeliharaan anak dalam hukum keluarga Islam. Urgensi dalam kajian pendidikan dalam tinjauan hukum keluarga Islam adalah menegaskan akan posisi orang tua yang tidak hanya bertugas memberikan nafkah, termasuk dalam soal keberhasilan dalam pendidikan. Kajian ini merupakan telaah konseptual, yang berusaha menggali 
Parenting Styles during the Covid-19 Pandemic.....

Baharuddin

DOI: $10.35673 /$ al-bayyinah.v4i2.788

konsep pangasuhan anak yang di bangun dalam hukum keluarga Islam. Temuan dalam penelitian ini menunjukkan bahwa pengasuhan anak menurut hukum keluarga Islam dalam situasi pandemi covid-19, yaitu: 1) mengajarkan anak berbuat kebaikan dan menjauhkan dari keburukan, hal ini dilakukan dengan cara orangtua memberi contoh serta mendampingi anak ketika belajar, 2) Mengasuh dengan kasih sayang, pengasuhan ini dilakukan dengan memberikan keselamatan dan pembimbingan pada anak, 3) Memenuhi kebutuhan anak. Dalam konsepsi hukum keluarga Islam dikenal dengan hak hadanah atau pemeliharaan anak yang dipahami secara luas, baik persoalan nafkah sampai pada kecerdasan anak. Implikais dari temuan ini bahwa di masa pandemi orangtua memiliki peran yang signifikan, di samping kebutuhan nafkah, orangtua juga dituntut untuk menjamin kecerdasan anak melalui keterpenuhan pendidikan.

Key Words: Parenting Styles; Child; Pandemic Period; Islamic Family Law.

\section{Introduction}

The Corona Virus Disease (covid-19) outbreak which has become a pandemic has made various groups of people feel anxious and worried. Living arrangements and sharing activities that are mostly carried out at home in order to reduce and prevent contracting Covid-19. Situations that require parents to stay with children at home in a covid-19 pandemic situation will have different habits and activities, these habits and activities are an additional task for families, especially parents. Parents work at home while providing full assistance to children, performing their roles and responsibilities as caregivers as well as teachers. This situation will create anxiety and worry for parents in carrying out their obligations as child caregivers.

The covid-19 pandemic situation will provide many changes including the way of caring for children that is very different from the previous situation. Childcare during the Covid-19 epidemic really needs to be considered and even very important because if not, then the child may not get their rights, even the child does not feel safe and protected. The hope of having and making pious children will certainly be difficult to achieve, due to the lack of good nurture. If this child's care is not given attention and priority, then the parents will be negligent in carrying out their obligations and can have an adverse effect on the child's future. ${ }^{1}$

One of the impacts is when parents ignore and do not apply good care, then they will act arbitrarily against the child and will even use physical and psychological

\footnotetext{
${ }^{1}$ Nurkholis, Dampak Pandemi Novel-Corona Virus Disiase (Covid-19) Terhadap Psikologi dan Pendidikan Serta Kebijakan Pemerintah. Jurnal PGSD, Vol. 6 (1) January-June 2020 (11), pp. 39. 49 , p. 42 .
} 
violence in acting and solving problems for the child. If this is what happens in parenting, the child will be greatly disadvantaged, even the child will have a bad personality and character. In response to this, by law and legislation, parents have committed negligence and violations in carrying out their duties as caregivers and in Islamic review, parents have been negligent of their obligations and responsibilities.

Islam has comprehensive teachings, providing assurance of life to every living being, even when humans are still in the form of fetuses. Islamic teachings have provided many guides and instructions and even instructions on how and what kind of obligations parents must fulfill in raising children. The obligation of parents in caring for the fulfillment of children's rights, the obligation of children to serve their parents is the fulfillment of parental rights. ${ }^{2}$

The juridical normative foothold related to protection and provision of children's rights and childcare can be found in Law Number 23 of 2002 concerning Child Protection, Law Number 35 of 2014 concerning Amendments to Law Number 23 of 2002, and Government Regulation Number 44 of 2017 concerning Implementation of Childcare. From several regulations, it is explained that every child has the right to survival, fulfillment of their rights and the right to protection from violence and discrimination as mandated in the 1945 Constitution. The main task of parents in caring for children as stated in the above rules is to try to provide love, protection and safety to children.

Parents have an obligation to care for their children as stated in several legal regulations in Indonesia and Islamic teachings, so it is very important for parents to apply care that can provide freedom, safety, security, growth and development without violence. Parents must carry out their duties very well, especially during the Covid-19 pandemic, because it can have an impact on the health, safety and survival of children. Parental care plays an important role in the family environment, parenting can be seen from the way parents care for, educate, guide, direct, and protect their children. ${ }^{3}$ The application of parenting style really needs to consider children's rights because parents have an obligation to provide protection both physically and psychologically.

From an Islamic perspective, Rasulullah (pbuh) has provided many examples of how to raise good children. As Muslim parents, they should emulate the Prophet Muhammad (pbuh) in raising children so that mistakes do not occur

${ }^{2}$ Hani Sholihah, Perlindungan Anak dalam Perspektif Hukum Islam, Jurnal Al-Afkar (Journal for Islamic Studies), Vol. 1 No.1 January 2018, E-ISSN: 2614-4905, P-ISSN: 2614-4883, DOI: 10.5281/zenodo.1161556, pp. 38-56, p. 38. p. 25 .

${ }^{3}$ Mahmud dkk, Pendidikan Agama Islam Dalam Keluarga, (Jakarta: Akademia Permata, 2013), 
and deviate from Islamic teachings, so that parents can carry out their duties properly. If there is an error in parenting, the child may not get their rights, even the child can get violence. Parents carry out their duties properly according to Islamic teachings so that their children will become pious children. ${ }^{4}$ Ibn Miskawih explained that parental care can have an influence on the formation of a child's personality. ${ }^{5}$ Therefore, parents must provide care based on Islamic teachings so that children have good personalities, so that their aqidah and morals are good.

In this regard, parents really need to prioritize and apply Islamic teachings which provide instructions and guidance on how parents can carry out their obligations in caring for even during the Covid-19 pandemic so that all children's rights can be fulfilled and the child will feel safe and protected. Of course this is what parents really need in situations that are less conducive, such as during the Covid-19 pandemic, so that it will reduce anxiety and worry in parenting. With a way of caring for children with an Islamic legal perspective, of course parents will find it very helpful and make it easier to carry out their duties and obligations even though there are huge challenges, namely the Covid-19 pandemic outbreak.

Therefore, the authors are interested in examining more deeply from various sources regarding how parents carry out childcare in the COVID-19 pandemic situation from the perspective of Islamic law. It is hoped that this paper can help and add insight and understanding to parents in caring for children with the perspective of Islamic law during the Covid-19 pandemic so that it can help and make it easier for them to carry out their obligations as caregivers, and help children fulfill their rights, get safety and protection from various dangers.

\section{Discussion}

\section{Parenting Styles}

Based on the literature of classical Islamic law (fiqh), the closest meaning to parenting is the word hadhānah. In terms of fiqh, hadhānah means taking care of a child or abnormal child who has not or is unable to live independently, namely by fulfilling their needs, protecting them from harm, providing them with education, and developing their potential to have a sense of responsibility. ${ }^{6}$ Besides hadhānah means taking care of small children, mentally disturbed people, weak people, people unable to be independent; meet education and various needs. ${ }^{7}$

${ }^{4} J a l a l u d d i n$, Mempersiapkan Anak Saleh, ( Jakarta: Srigunting, 2002), p. 4-5.

${ }_{5}^{5}$ Pajrin, Pola Asuh Anak dalam Perpektif Pendidikan Islam, Jurnal Intelektulita Vol. 5 No. 1, June 2016, pp.1-16, p. 5.

${ }^{6}$ Abdul Aziz Dahlan (Ed.), Ensiklopedi Islam (Jakarta: Ichtiar Baru van Hoeve, 2005). Vol. 2, p. 229.

${ }^{7}$ Abdurrahman al-Jaziri, Kitab al-Figh 'alā al-Mazāhib al-Arba`ah, (Kairo: Dar al-Hadits, without year), Vol. IV, p. 582. 
According to Wahbah, hadhānah is educating and caring for people who are not yet independent to handle personal matters of things that they do not like. As for people who are not independent, are people who have not been able to take care of themselves, such as eating and clothing, things that are not independent, namely children who have not yet grown up. As for what can be done for these children by providing protection, fulfilling needs, and teaching various things, especially religious teachings. ${ }^{8}$

One of the works of As-Syyid Sabiq in his book Fiqh as-Sunnah explains that the hadhānah nurtures and nurtures children who are not yet male and female until he is able to be independent and responsible. Things that can be done in the care of children by helping to develop their potential, maintaining physical and spiritual health and providing protection from harm. In addition, there is an obligation to care for children, it is even emphasized that the law is compulsory (wajib). The thing that makes it obligatory to take care of children is that if it is not done, the child will be neglected so that it can be in a dangerous situation. ${ }^{9}$ From this opinion, it can be understood that the importance of good care for children is even stated that the law is mandatory.

Furthermore, according to Darajat, parenting is a perfect totality of attitudes and treatment given to children from birth by parents, both in terms of educating, fostering, tutoring, and familiarizing children in various ways according to the instructions in the Quran and Hadith. ${ }^{10}$ In this case, parents as caregivers certainly have an important role in making children have aqidah and good morals as recommended in Islam.

With regard to parenting rights, the Law has explained in detail in article 45 paragraphs 1 and 2 of Law Number 1 of 1974 concerning Marriage that article reads: (1) both parents are obliged to care for and educate their children as well as possible and (2) The obligations of the parents as meant in paragraph (1) of this article shall be valid until the child is married or can be independent, which obligations shall continue even if the marriage between the two parents breaks up. In this law, it has been stipulated that parents (father and mother) have the obligation to care for their children, care is carried out until the child is able to be independent or is married, even in this regulation even though parents (father and mother) have been divorced but still have obligations in caring .

\footnotetext{
${ }^{8}$ Wahbah al-Zuhaili, Al-Fiqh al-Islami wa Adillatuh, (Damsyiq : Dar al-Fikr, 1989), VII, p. 718.

${ }^{9}$ As-Sayyid Sabiq, Fiqh Sunnah, (2 ${ }^{\text {nd }}$ Print; Beirut: Dar al-Fikr, 1983), p. 288.

${ }^{10}$ Zakiah Daradjat, Membina Nilai-nilai Moral Indonesia, (Jakarta: Bulan Bintang, 1985), p.
} 34. 
In line with what was conveyed by the Prophet Muhammad in his Hadith relating to the responsibilities of parents (father and mother) in caring for children, namely: "A man is a leader in his family and he is responsible for his leadership. And a woman is also a leader in her family and she is responsible for her leadership." (Hadith narrated by Al-Bukhari and Muslim). ${ }^{11}$ The meaning of the hadith is that a man and a woman are father and mother (parents), in this case, the leaders who have duties and responsibilities to their children. Therefore, it is understood that those who are responsible for carrying out the care of children are the parents (father and mother).

\section{The Concept of Parenting in Islamic Family Law}

Caregiving is a parent's obligation that must be carried out and the child's right to get care and care. This must be fulfilled for the benefit and survival of the child, even it is the absolute responsibility of parents to their children. Islam as a teaching that guarantees the life of every living being, including children, it is the parents who have the responsibility in choosing and caring for the child. The initial goal of Islamic law is the benefit of mankind in the world and the hereafter, ${ }^{12}$ the purpose of Allah to make the law is to maintain the benefit of the people while avoiding bad consequences (mafsadat), ${ }^{13}$ and one way is to carry out good and quality children's education.

Parents as the most responsible for child care as quoted from Muhamad Anshori, Abdullah bin Umar radhiallahu 'anhuma said, "Educate your children, because in fact you will be held accountable for the education and teaching that has been given to the child. And he will also be asked about your kindness to him and obedience to you ". ${ }^{14}$ What is stated by Abdullah bin Umar, it is clear that there are orders to parents in caring for children, even what parents give in caring for children, in the form of education, guidance, fulfillment of rights, and provision of food or clothing, they will definitely be held accountable. Therefore, parents should provide good care for their children so that they can be held accountable in the afterlife.

${ }^{11}$ Muhammad Nur Abdul Hafizh Suwaid. Prophetic Parenting: Cara Nabi SAW Mendidik Anak, (Yogyakarta: Pro-U Media, 2010), p. 47.

${ }^{12}$ Sitti Najmah, "Memahami Konsep Maqashid Al-Syari'ah Dalam Filsafat Hukum Islam." AL-BAYYINAH 1.1 (2017): 43-58.

${ }^{13}$ Hamzah Latif. " Telaah Maqasid Syariah Terhadap Putusan MK No. 22/PUU-XV/2017 Tentang Batas Usia Nikah." ALSYAKHSHIYYAH: Jurnal Hukum Keluarga Islam dan Kemanusiaan 1.1 (2019): 61-84.

${ }^{14}$ Muhamad Anshori, Perspektif Al-qur'an Tentang Pendidikan Keluarga, Dirasah: Jurnal Pemikiran dan Pendidikan Dasar Islam. Vol. 2, No. 2, August 2019, e.ISSN-2598-7488, p. 37-48. 
In connection with the obligation of parents to care for children, it must be carried out and fulfilled. Parents should not be negligent, especially to the point of leaving their obligations as caregivers, because that could be a crime committed by the parents. This was confirmed by Ibnul Qayyim, "Anyone who deliberately does not teach what is good for his child and just leaves him (does not want to nurture), means he has committed a very big crime. The damage that occurs to children, one of the reasons is because parents leave foster care and do not teach anything useful that comes from religious teachings". ${ }^{15}$ What was stated by Ibnul Qayyim, it is clear that parents should provide good care for their children in order to avoid violations and even crimes that will befall the parents.

Islamic teachings have clearly taught how to raise children, this is what parents need to do in fulfilling their obligations. From several sources, there are ways of caring for children based on Islamic teachings, including: First, parents teach children to do good and keep away from evil. As parents, of course, they want their children to always do good and not do bad things. This is what parents need to realize, that this desire can be achieved if the parents are at the forefront of teaching or giving examples of kindness to their children. Pleased with this, then there is actually an order from Allah SWT., To parents to take care of themselves and their families as the word of Allah SWT., In QS. At-Tahrim/66 verse 6:

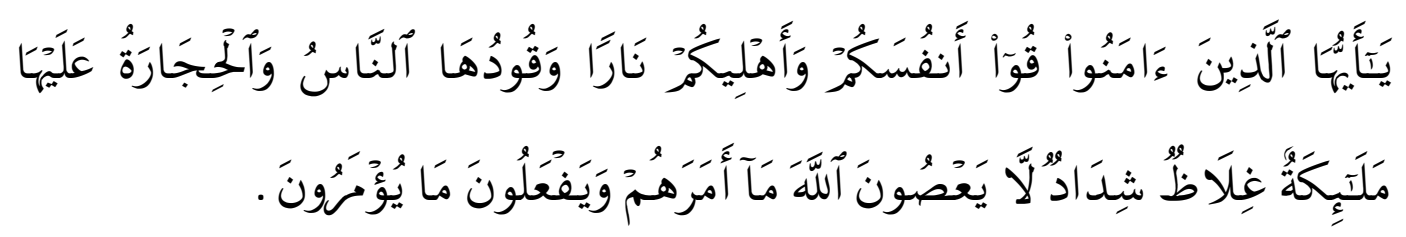

The translation:

O believers! Protect yourselves and your families from a Fire whose fuel is people and stones, overseen by formidable and severe angels, who never disobey whatever Allah orders-always doing as commanded. ${ }^{16}$

Regarding the above verse, Ali bin Abi Talib in interpreting the word of Allah "take care of yourself and your family in hell fire", he said that teach yourself and your family for good ", in line with what Muqatil said, let a Muslim to empower himself and his family to always do good and keep away from evil. ${ }^{17}$ Therefore, one of the duties of parents in caring for their children is to always teach children to

\footnotetext{
${ }^{15}$ Muhammad Nur Abdul Hafizh Suwaid. Prophetic Parenting: Cara Nabi SAW Mendidik Anak, (Yogyakarta: Pro-U Media, 2010), p. 51.

${ }^{16}$ al-Mehri, A. B. (Ed.). The Qur'ān: With Sürah Introductions and Appendices: Saheeh International Translation (Maktabah Booksellers and Publishers, 2010), p. 951

${ }^{17}$ Muhammad Nur, A. Prophetic Parenting: Cara Nabi SAW Mendidik Anak.......... p. 51
} 
always do good for themselves and others, and lead children to stay away from and not do bad things. If parents are able to do this, it means that he has provided salvation for him and his family both in this life in this world and in the hereafter.

Furthermore, the second, parenting children with great affection. Islam as a religion which is a blessing for every living being is very concerned about protecting children. One of them is to provide pictures and instructions to parents in providing loving care. Parents can give affection to their children by giving appreciation, meeting children's needs and being at the forefront of providing protection. In connection with the importance of giving love to children, as recommended by the Prophet Muhammad (pbuh), in his hadith narrated by Abu Hurairah radhiallahu 'anhuma: From Abu Hurairah r.a., "that Aqra' bin Habis saw the Prophet (pbuh) kissed Hasan, then said: "Verily I have ten children and not one of them I have ever kissed." Rasulullah saw. then said: "Verily, whoever does not love, will not be loved." 18

The hadith above, explains how Rasulullah (pbuh) provided an example to his companions in parenting children. One thing that parents can do in providing care for their children is by always prioritizing affection, even from the Hadith it is explained that one of the conditions to be loved is to love. This means that when parents apply compassion when carrying out parenting, it could be Allah SWT., Will also give love and the children will love their parents. If this is what parents do in caring for children, it will give birth to love among them so that it can bring happiness and peace.

Furthermore, the third one, meeting the needs of children. Every child has rights and needs that parents should give them the right thing to do. The provision of children's needs should be done by parents, because it is their obligation. However, if there are parents who do not provide the rights and needs of the child, it means that they violate religious advice, even including people who neglect their children, which is of course very opposed to the law on child protection. As for the purpose of providing children's needs to continue their life and avoid misery. ${ }^{19}$

Parents, in fulfilling children's needs and rights, can take the form of providing a living, food, facilities, health and protection. Providing needs is very important for children, even though parents are not able to fully fulfill the children's needs, the government and society can provide assistance because providing children's needs is a shared responsibility. Therefore, parents should not argue that they do not try to provide for their children, especially in Islam, it is

\footnotetext{
${ }^{18}$ Muslim, Shahih Muslim, Chapter 2, p. 325.

${ }^{19}$ Iim Fahimah, Kewajiban Orang Tua terhadap Anak dalam Perspektif Islam. Jurnal Hawa. Vol. I No. I 2019, p. 35-50
} 
Parenting Styles during the Covid-19 Pandemic.....

Baharuddin

DOI: $10.35673 /$ al-bayyinah.v4i2.788

described that every creature, including parents and children, has been given and determined for their respective sustenance, as Allah Swt., has said in QS. Al-Isra/17 verse 31:

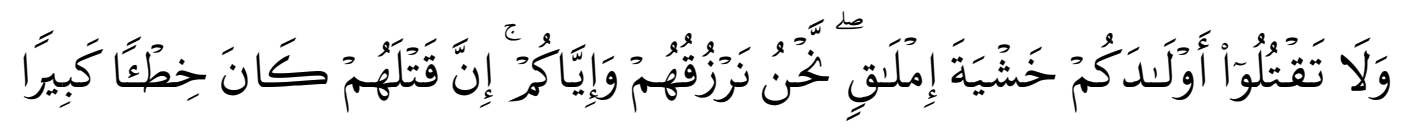

The Translation:

Do not kill your children for fear of poverty. We provide for them and for you. Surely killing them is a heinous sin. ${ }^{20}$

In the above verse, Allah strictly forbids parents to kill their children because they only cannot provide a living, especially because they are afraid of being poor. Every human being has been provided with sustenance by Allah, including parents and children. Therefore, parents do not need to be afraid of being poor just because they provide their children with necessities (a living). In fact, this can be the value of alms worship for themselves. This is where the efforts and understanding of parents are needed to meet the child's needs appropriately, it does not mean that they have to comply with all the desires of the child. Providing children's needs really needs to consider priority and main because there are still many other family needs and this is also for the good of the child so that it doesn't become a negative influence.

Regarding the provision of support for children by parents, Imam Syafi'i explained that a husband (father) is obliged to support his children until they reach maturity (baligh). After the child goes to life, there is no longer the obligation of the parent to provide the necessities (living) to the child, but if the parent still wants to provide a living, especially if the child does not have a job or is experiencing shortages, then it is recommended. ${ }^{21}$ Most importantly, as parents, they will still be considered as caregivers to their children, but the way of caring for them will be different when the child is older.

\section{Parenting Style during the Pandemic and Its Correlation to Islamic Family Laws}

The government is currently preoccupied with the covid-19 pandemic, various policies have been carried out starting with physical distancing and PSBB (large-scale social restrictions) as a way to reduce the spread and end of the Covid-19 pandemic. With this policy, making all activities carried out at home, including in this case children's activities. Children who previously studied at school but their

\footnotetext{
${ }^{20}$ al-Mehri, A. B. (Ed.). The Qur'ān: With Sürah Introductions and Appendices: Saheeh International Translation (Maktabah Booksellers and Publishers, 2010), p. 429

${ }^{21}$ Muhammad Nur, A. Prophetic Parenting: Cara Nabi SAW Mendidik Anak...h. 153
} 
learning is diverted through an online system which is carried out at home, even all children's activities are carried out at home, be it studying, playing and worshiping. This is done because according to information from WHO that the most vulnerable group to be affected by Covid-19 are children, even children can be the most affected victims. ${ }^{22}$

In response to this situation, the UNICEF organization as a forum that protects the rights of children around the world has launched the "Global Agenda", which aims to provide protection to children around the world from this outbreak. The contents of the pillars of the agenda: 1) Keeping children healthy; 2) Reaching vulnerable children with water, sanitation and hygiene; 3) Keep children learning; 4) the need for family support to meet the needs and care for their children; 5) Protect children from violence, exploitation and abuse; and 6) Protect refugee and migrant children, and those affected by conflict. ${ }^{23}$ It is hoped that the contents of the pillars of the agenda can be realized with the cooperation among the family, community and government in order to maintain the survival and health of children.

Changes in all children's activities at home due to the Covid-19 pandemic can be used by parents as best as possible because of more time together. Parents who are the main pioneers in protecting children from all dangers as well as caregivers who have the obligation to continue the child's life that is more proper and better. So this is where the role of parents is needed to always help children in responding to situations that are not conducive, so that children's health remains stable and maintained, children can explore their potential, and children can still enjoy their happiness.

Islam is present as a teaching that always provides solutions at all times, including in unfavorable conditions such as the covid-19 outbreak. In these conditions, parents do not need to be too worried and anxious because they are unable to carry out their duties properly as caregivers. In Islamic teachings, it is clear what the Qur'an and Hadith say about how parents provide care for their children, including being able to be conditioned according to the situation or circumstances. This shows how the teachings of Islam have perfection in providing guidance and solutions to every living being, including parents and children for what is experienced. Attention to the fulfillment of children's rights shows how

\footnotetext{
${ }^{22}$ Noorani, Jangan biarkan anak-anak menjadi korban tersembunyi pandemi COVID-19, Sembilan puluh sembilan persen anak-anak di dunia hidup dengan beberapa bentuk pembatasan gerakan terkait pandemi; Enam puluh persen tinggal di negara-negara dengan lockdown penuh atau sebagian, https://www.unicef.org/indonesia/id/press-releases/jangan-biarkan-anak-anak-menjadi-korbantersembunyi-pandemi-covid-19, UNICEF Indonesia for Every Child, accessed on 27 June 2020, at $10: 15$

${ }^{23}$ Noorani, Jangan biarkan anak-anak menjadi korban tersembunyi pandemi COVID-19
} 
Parenting Styles during the Covid-19 Pandemic.....

Baharuddin

DOI: $10.35673 /$ al-bayyinah.v4i2.788

Islamic teachings can be accepted by anyone and anywhere, even before various countries made declarations and established organizations to protect and save children's lives. ${ }^{24}$

Parenting for children in the perspective of Islamic law means that parents fulfill children's rights and provide protection and safety from various dangers. Therefore, parents who have given children's rights, provided protection and safety and taken care of their children's health are considered to be doing their obligations under Islamic law. This is what is expected of parents, because children who are cared for are a blessing and a mandate from Allah Swt., that will be held accountable by the parents in the afterlife.

In connection with the Covid-19 pandemic period, it is very necessary to consider proper care methods so that children can still get their rights and can maintain their health. From various sources, there are three ways of parenting that can be done by parents in raising children based on Islamic teachings, 1) Parents teach children to do good and keep away from badness, 2) care for children with love, and 3) meet children's needs. How do you do this care during the Covid-19 pandemic? And how does Islamic law respond? The author will describe how it is implemented and how Islamic law reacts to it.

The first parenting that parents can do is to teach children to do good and keep away from evil. The way that parents can do to teach their children goodness during the Covid-19 pandemic is by giving examples, for example: when it is time for prayer, parents can invite children to pray in congregation by dividing tasks. The child who pronounces the call to prayer (adzan), while the father becomes the imam, the mother and child can become the ma'mum. So parents not only tell children to do good but set an example, because what does it mean if parents only send children but they do not do good. Then the way parents forbid their children to do bad things, can also be by setting an example. For example, parents prohibit their children from speaking harshly or telling lies, so it is better if parents talk to children they should use polite language and convey truthfully or honestly.

Regarding children's learning activities at home, however, if parents have insufficient knowledge, they can assist or accompany the child while learning, as well as communicate with the teacher to ask for help for the smooth and successful learning process of children at home. This is part of the parents' efforts to provide kindness to their children even though it is not possible in terms of knowledge. So parents who feel that they are less capable of teaching goodness (knowledge) may

${ }^{24}$ Hani Sholihah, Perlindungan Anak dalam Perspektif Hukum Islam, Jurnal Al-Afkar (Journal for Islamic Studies), Vol. 1 No.1 January 2018, E-ISSN: 2614-4905, P-ISSN: 2614-4883, DOI: 10.5281/zenodo.1161556, pp. 38-56, p. 52-53. 
ask for help from others, but cannot fully surrender, it must still be controlled because childcare is still the responsibility of the parents.

Parents who always try to teach goodness to their children as proof of their obedience to Allah have given something very valuable to their children. This is as said by the Prophet Muhammad (pbuh) in his hadith narrated by Al-Hakim, "There is no greater and more valuable gift from parents to their children than good teaching". (Hadith narrated by Al-Hakim) ${ }^{25}$ Apart from that what was conveyed by Abu alHamid al-Ghazali, "whoever gives good upbringing (teaching) to the child, whether it is parents or others will get rewarded as a child will get reward for the good he did. On the other hand, if they are accustomed to ugliness and even just let it go, then every sin they commit will be borne by those who are obliged to take care of them." (Ihya Ulum al-Din 3/72). ${ }^{26}$

Parents' care in the first way (teaching kindness and prohibiting badness) during the Covid-19 pandemic, when viewed from Islamic law, is considered to have fulfilled their obligations as a caregiver. However, when parents leave it to other parties to ask for help in order to teach goodness to their children because of the lack of knowledge of the parents, they do not intend to neglect (not intentionally) then it is considered to have fulfilled their obligations as caregivers. As Ibnul Qayyim said, "Whoever deliberately does not teach what is beneficial to his child and just leaves it (does not want to take care of it) then that is what people consider to be negligent of their obligations." ${ }^{27}$ Benefit as the substance of the syari'at experiences differences along with the different times, places, situations, intentions, and customs. That means that the occurrence of different times, places, situations, intentions, and customs becomes the legitimacy and reason for the change in law. The view of al-Jauziyah shows that Islamic syari'at is flexible and adaptive in responding to any changes and developments. The opinion of alJauziyah argues that Islamic law can be interpreted and translated according to the social context of the people. ${ }^{28}$ Hence, with the education of children during the Covid-19 period, they must adapt to the conditions of the times.

Furthermore, the second way parents can take care of their children during the Covid-19 pandemic is by providing love. Parents' love for children is a gift of such high value that it is even a tribute to the child. With this affection that exists

\footnotetext{
${ }^{25}$ Muhammad Nur, A. Prophetic Parenting: Cara Nabi SAW Mendidik Anak...h. 335

${ }^{26}$ Muhammad Nur Ichwan Muslim, Pendidikan Anak Tanggung Jawab Siapa? https://muslim.or.id/20835-pendidikan-anak-tanggung-jawab-siapa.html, accessed on 27 June 2020, at $08: 45$.

${ }^{27}$ Muhammad Nur, A. Prophetic Parenting: Cara Nabi SAW Mendidik Anak. ...p. 51

${ }^{28}$ Sitti Rahmawati, Paradigma Perubahan Hukum Islam (Eksplorasi Pemikiran Ibnu Qayyim al-Jauziyah)." Al-Bayyinah 1.2 (2017): 17-28.
} 
between parents and children, it will create harmony and tranquility in the family environment. Loving parental care is the key to successful parenting because the child will feel safe, be given his rights and feel protected by his parents.

The covid-19 pandemic has made changes to children's activities, even all activities are carried out at home. This is a valuable opportunity for parents to express their love for their children through parenting. As for how parents care for their children by providing as much detail as possible about covid-19, what children should do and how to avoid getting infected. For example, teaching children to love cleanliness in the surrounding environment or getting children to wash their hands with soap when they have handled an object that is not clean, then maintaining distance (physical distancing) when outside the house.

In addition, the most important thing is to apply love to children during the Covid-19 pandemic, to provide opportunities to talk to children when they make mistakes. So parents do not immediately give punishment or sanctions because this can affect their mental health which reduces the child's immunity, but gives the child the opportunity to tell what really happened. The most important thing parents do at times like this is how to guide them to correct children's mistakes instead of being tedious, so parents give or teach how children should be done so they do not make the same mistakes again.

Parents' care by sharing information about the dangers and how to avoid the Covid-19 outbreak as well as guidance in correcting mistakes, includes part of providing protection for children from harm and granting respect for children. When viewed from Islamic law, parents have fulfilled their obligations as caregivers.

Furthermore, the last way of parenting that parents can do during a pandemic, provides for children's needs. Every child, both boy and girl, has the right to get his needs (living), the one who is most responsible for providing for the child's needs is the parent. Providing needs for children is very important for the sake of security and fulfillment of children's rights. ${ }^{29}$

To carry out this method of care during the Covid-19 pandemic, of course parents provide the children with what they need, such as proper clothes, halal food and drinks that are good and good, and supporting facilities. However, parents need to control what needs their children prioritize because they do not want children to ask for things that are out of the ordinary. In providing a living, it is necessary to consider the economic problems of the family, especially during the

${ }^{29}$ Tawaduddin, Pola Pengasuhan Alternative Dual Career Family dalam Pemenuhan Kebutuhan Asih Anak, Journal of Chilidhood Education, Vol. 2 No. 2 2019, p-ISSN: 2598-2484, eISSN: 2620-3278, p. 1-12. 
Parenting Styles during the Covid-19 Pandemic.....

Baharuddin

DOI: $10.35673 /$ al-bayyinah.v4i2.788

Covid-19 pandemic. So parents can provide for children's needs that are considered important, but they must not force it, even more so, they have to borrow to fulfill children's requests. Likewise, parents who have sufficient assets should not be too over or exceed the limit in providing for their children's needs because it is not wasteful.

The importance of providing and fulfilling a living for children is not only the responsibility of parents alone, but the community and government are also responsible, especially in the conditions of the Covid-19 pandemic. The government's involvement in helping the family economy during the Covid-19 pandemic with the distribution of direct cash assistance (BLT) received every month, is expected to reduce the burden and help parents in meeting children's needs. So parents should not be independent with regard to fulfilling children's needs, they must keep trying because that is part of their responsibility as a caregiver.

Responding to this regarding the fulfillment of children's needs by parents during the Covid-19 pandemic, according to Islamic law it is deemed to have fulfilled its obligations. As the opinion of Asy-Shaykh al-Allamah Abdurrahman asSa'di rahimahullah said, if parents have met children's needs such as food, clothing, and basic services, they are considered to be doing their obligations as caregivers, even what parents do in meeting children's needs, it is considered to have goodness. $^{30}$

The Covid-19 pandemic presents many challenges to anyone, including in this case parents, even though conditions are not conducive, parents as carers of children still have an obligation to carry out their responsibilities. However, in the midst of the Covid-19 pandemic, it is true that parents need to choose the right way of care in order to continue to carry out their obligations as caregivers. Proper parenting will have a positive influence on the child and will even have an influence on moral development until the child enters adulthood. ${ }^{31}$ This means that the treatment of parents in parenting will determine the attitude and morals of the child in the future. One of the ways that parents can do in carrying out their duties is parenting based on Islamic teachings.

\section{Conclusion}

A different situation during the Covid-19 pandemic gave parents the opportunity to maximize their role. Parenting for children in the perspective of Islamic family law means that parents fulfill children's rights and provide protection

\footnotetext{
${ }^{30}$ Muhammad Nur, A. Prophetic Parenting: Cara Nabi SAW Mendidik Anak...h. 154

${ }^{31}$ Djawad Dahlan, Psikologi Perkembangan Anak dan Remaja. (Bandung: PT. Remaja Rosdakarya, 2014), p. 14.
} 
Parenting Styles during the Covid-19 Pandemic.....

Baharuddin

DOI: $10.35673 /$ al-bayyinah.v4i2.788

and safety from various dangers. Parents as caregivers of children have a central role in providing protection and safety for children, therefore it requires proper parenting in unfavorable situations and conditions. Keep children away from bad things that can damage children's morals. In the care of children in Islamic family law describes the rights of hadanah or the right to care for children. Tracing further in Islamic family law, childcare does not only reach the fulfillment of children's livelihoods, but parents must guarantee children's education, so that children become intelligent and noble human beings.

\section{References}

Al-Jaziri, Abdurrahman . Kitab al-Fiqh `alā al-Mazāhib al-Arba`ah, (Kairo: Dar alHadits, without year), Volume IV.

al-Mehri, A. B. (Ed.). The Qur'ān: With Sürah Introductions and Appendices: Saheeh International Translation. Maktabah Booksellers and Publishers, 2010.

Al-Zuhaili, Wahbah. Al-Fiqh al-Islami wa Adillatuh, (Damsyiq: Dar al-Fikr, 1989), VII.

Anshori, Muhammad. Perspektif Al-qur'an Tentang Pendidikan Keluarga, Dirasah: Jurnal Pemikiran dan Pendidikan Dasar Islam. Vol. 2, No. 2, August 2019, e.ISSN-2598-7488.

Dahlan, Abdul Aziz (Ed.). Ensiklopedi Islam (Jakarta: Ichtiar Baru van Hoeve, 2005). Vol. 2.

Dahlan, Djawad. Psikologi Perkembangan Anak dan Remaja. (Bandung: PT. Remaja Rosdakarya, 2014).

Daradjat, Zakiah. Membina Nilai-nilai Moral Indonesia, (Jakarta: Bulan Bintang, 1985).

Fahimah, Iim. Kewajiban Orang Tua terhadap Anak dalam Perspektif Islam. Jurnal Hawa. Vol. I No. I 2019.

Idawati. Peran Orang Tua dalam Membentuk Krakter Agama pada Anak, Media Binah Ilmiah: Ejurnal Binawakya, Vol.14 No.7 February 2020, p- ISSN: 1978-3787, e- ISSN: 2615-3505.

Jalaluddin. Mempersiapkan Anak Saleh, ( Jakarta: Srigunting, 2002).

Latief, Hamzah. " TELAAH MAQASID SYARIAH TERHADAP PUTUSAN MK NO. 22/PUU-XV/2017 TENTANG BATAS USIA NIKAH." ALSYAKHSHIYYAH: Jurnal Hukum Keluarga Islam dan Kemanusiaan 1.1 (2019): 61-84. 
Parenting Styles during the Covid-19 Pandemic.....

Baharuddin

DOI: $10.35673 /$ al-bayyinah.v4i2.788

Mahmud dkk, Pendidikan Agama Islam Dalam Keluarga, (Jakarta: Akademia Permata, 2013).

Muslim, Muhammad Nur Ichwan, Pendidikan Anak Tanggung Jawab Siapa? https://muslim.or.id/20835-pendidikan-anak-tanggung-jawab-siapa.html, accessed on 27 June 2020, at 08:45.

Najmah, Sitti. "Memahami Konsep Maqashid Al-Syari'ah Dalam Filsafat Hukum Islam." AL-BAYYINAH 1.1 (2017): 43-58.

Nurkholis. Dampak Pandemi Novel-Corona Virus Disiase (Covid-19) Terhadap Psikologi dan Pendidikan Serta Kebijakan Pemerintah. Jurnal PGSD, Vol. 6 (1) January-June 2020 (11), pp. 39-49.

Noorani, Jangan biarkan anak-anak menjadi korban tersembunyi pandemi COVID19, Sembilan puluh sembilan persen anak-anak di dunia hidup dengan beberapa bentuk pembatasan gerakan terkait pandemi; Enam puluh persen tinggal di negara-negara dengan lockdown penuh atau sebagian, https://www.unicef.org/indonesia/id/press-releases/jangan-biarkan-anakanak-menjadi-korban-tersembunyi-pandemi-covid-19, UNICEF Indonesia for Every Child, accessed on 27 June 2020, at 10:15.

Pajrin. Pola Asuh Anak dalam Perpektif Pendidikan Islam, Jurnal Intelektulita Vol. 5 No. 1, June 2016, pp.1-16.

Rahmawati, Sitti. "PARADIGMA PERUBAHAN HUKUM ISLAM (Eksplorasi Pemikiran Ibnu Qayyim al-Jauziyah)." Al-Bayyinah 1.2 (2017): 17-28.

Sholihah, Hani. Perlindungan Anak dalam Perspektif Hukum Islam, Jurnal Al-Afkar (Journal for Islamic Studies), Volume 1 No.1 January 2018, E-ISSN: $2614-$ 4905, P-ISSN: 2614-4883, DOI: 10.5281/zenodo.1161556, pp. 38-56.

Sabiq, As-Sayyid. Fiqh Sunnah, (Beirut: Dar al-Fikr, 1983) $2^{\text {nd }}$ Print.

Suwaid, Muhammad Nur Abdul Hafizh. Prophetic Parenting: Cara Nabi SAW Mendidik Anak. Yogyakarta: Pro-U Media, 2010.

Tawaduddin. Pola Pengasuhan Alternative Dual Career Family dalam Pemenuhan Kebutuhan Asih Anak, Journal of Chilidhood Education, Vol. 2 No. 2 2019, p-ISSN: 2598-2484, e-ISSN: 2620-3278. 